\title{
A comparison of the efficacy of latanoprost, travoprost and bimatoprost in open angle glaucoma and ocular hypertension
}

\author{
Özlem Eşki Yücel ${ }^{a *}$, Nurşen Arıtürk ${ }^{b}$ \\ Department of Ophthalmology, Research and Education Hospital, Samsun, Turkey \\ Department of Ophthalmology, Ondokuz Mayıs University, Medical Faculty, Samsun, Turkey
}

\begin{tabular}{|c|c|}
\hline \multicolumn{2}{|c|}{ ARTICLE INFO } \\
\hline \multicolumn{2}{|c|}{ Article History } \\
\hline Received & 15 / 06 / 2011 \\
\hline Accepted & 15 / $07 / 2011$ \\
\hline
\end{tabular}

* Correspondence to

Özlem Eşki Yücel

Samsun Eğitim ve Araştırma Hastanesi, Göz Hastalıkları Kliniği

İkadım/Samsun, Türkiye

Email: drozlem38@hotmail.com

\section{Keywords:}

Primary open angle glaucoma

Ocular hypertension

Latanoprost

Travoprost

Bimatoprost

\begin{abstract}
The aim of this study was to compare the efficacy and safety of latanoprost, travoprost and bimatoprost monotherapies in previously untreated patients with open angle glaucoma and ocular hypertension. This study included thirty-six eyes of 18 patients diagnosed with primary open angle glaucoma (POAG) and ocular hypertension (OHT) at Ondokuz Mayıs University, Medical Faculty, Department of Ophthalmology. All patients were underwent complete ophthalmic examination. Patients were randomized into 3 groups with six patients; group 1 received latanoprost $0.005 \%$ (Xalatan, Pharmacia), group 2 received travoprost $0.004 \%$ (Travatan, Alcon) and group 3 received bimatoprost $0.03 \%$ (Lumigan, Allergan) monotherapies. First examination was performed at the beginning of the study. Control examinations were performed at the 2, 4, 12 and 24th weeks of the therapy. Efficacy and side effects of these drugs were evaluated on each control visits. There were no significant differences in demographic characteristics among treatment groups. Baseline mean intra ocular pressure (IOP) levels were $26.50 \pm 3.14 \mathrm{mmHg}$ in group 1, 25.58 \pm 3.62 $\mathrm{mmHg}$ in group 2 and $24.66 \pm 3.62 \mathrm{mmHg}$ in group 3. Mean IOP levels were similar at end of the study between groups and $14.83 \pm 2.24 \mathrm{mmHg}$ in group $1,16.41 \pm 4.16 \mathrm{mmHg}$ in group 2 and $16.16 \pm 3.53 \mathrm{mmHg}$ in group 3. The most frequent side-effect was conjunctival hyperemia, which was determined in none of the patients in group 1, in 2 eyes in group $2(16.7 \%)$ and 6 eyes in group $3(50 \%)$. There was no statistically significant difference of IOP between latanoprost, travoprost and bimatoprost monotherapies. The side-effects were fewest in the latanoprost group and the most frequent in the bimatoprost group.

J. Exp. Clin. Med., 2012; 29: S89-S92
\end{abstract}

\section{Introduction}

Glaucoma is one of the most common causes of irreversible blindness. In fact, it is an optic neuropathy characterized by high intra ocular pressure (IOP), visual field (VF) loss and pathological cupping in the optic disc (Smith and Doyle, 2004). The most important treatable risk factor for glaucoma is IOP. The main aim of the glaucoma treatment is reduction of IOP (AGIS Investigators, 2000). Medical and surgical procedures may be essential for reducing IOP. The first choice of treatment is topical drops. Prostaglandin analogs (PGAs) are the most effective hypotensive drugs for the treatment of primary open-angle glaucoma (POAG) and ocularhypertension (OHT) (Alexander et al., 2002). PGAs reduce IOP by increasing aqueous humor outflow through the uveoscleral pathway (Turaçli, 2003). The fact that PGAs are more effective than classical anti-glaucoma agents and have minimal systemic side-effects has led them to be preferred in the treatment of POAG and OHT (Watson and Stjernschantz, 1996; Net- land et al., 2001; Sherwood and Brandt, 2001). Latanoprost $(0.005 \%)$, travoprost $(0.004 \%)$ and bimatoprost $(0.03 \%)$ are currently available PGAs in Turkey.

This study was performed to compare the efficacy and safety of latanoprost, travoprost and bimatoprost monotherapies in POAG and OHT treatment.

\section{Materials and methods}

Thirty-six eyes of 18 patients who admitted to glaucoma unit of our clinic were included into this study. All subjects had POAG or OHT. Patients who had narrow angle, secondary glaucoma (neovascular glaucoma, angle recession glaucoma, üveitic glaucoma), or were receiving combination of medical and surgical therapy were excluded. Also patients with poor compatibility with treatment and follow-up were not included. All patients were informed about the study, and gave written informed consent.

A complete ophthalmic examination including Snellen 
visual acuity measurement, slit-lamp biomicroscopy, IOP measurement with Goldman applanation tonometry, gonioscopy with a Goldman three mirror lens, ophthalmoscopy, central corneal thickness (CCT) measurement with ultrasonic pachymetry (UP-1000 Ultrasonic Pachimeter Nidec) and visual field (VF) evaluation with a Humphrey FAII perimeter (Humprey Instruments A Division of Carl Zeiss) were applied for all patients. All of the IOP measurements were performed at eight o'clock in the morning.

\section{Table 1. Demographic and baseline characteristics}

\begin{tabular}{lccc} 
& Latanoprost & Travoprost & Bimatoprost \\
\hline $\begin{array}{l}\text { Number of cases } \\
\text { Number of eyes }\end{array}$ & 6 & 6 & 6 \\
Mean age (years) & $56.50 \pm 7.83$ & $55.16 \pm 9.31$ & $62.50 \pm 10.17$ \\
$\begin{array}{l}\text { Range of age } \\
\text { (years) }\end{array}$ & $45-68$ & $41-69$ & $48-75$ \\
$\begin{array}{l}\text { Sex (Female/ } \\
\text { Male) }\end{array}$ & $3 / 3$ & $3 / 3$ & $1 / 5$ \\
$\begin{array}{l}\text { Baseline IOP* } \\
\text { (mmHg) }\end{array}$ & $26.50 \pm 3.14$ & $25.58 \pm 3.62$ & $24.66 \pm 3.62$ \\
C/D Ratio** & $0.45 \pm 0.18$ & $0.41 \pm 0.23$ & $0.38 \pm 0.21$ \\
CCT ( $\mu$ m)*** & $551.66 \pm 18.74$ & $571.25 \pm 47.54$ & $576.41 \pm 25.72$ \\
\hline
\end{tabular}

*: Intra Ocular Pressure

**: Cup/Disk Ratio

***: Central Corneal Thickness

Patients were randomized into 3 groups according to age, gender and glaucoma type; group 1 received latanoprost $0.005 \%$ (Xalatan, Pharmacia), group 2 received travoprost $0.004 \%$ (Travatan, Alcon) and group 3 received bimatoprost $0.03 \%$ (Lumigan, Allergan) monotherapies. Drugs were administered at a single daily dose at 22:00 PM. Patients were invited to control examinations at the 2, 4, 12 and 24th weeks of the therapy and evaluated in terms of IOP and side effects including stinging/burning, itching, conjunctival hyperemia, hypertrichosis, eyelid erythema, pigmentation in the iris and periocular skin or cystoid macular edema.

The statistical analyses were performed using the Statistical Package for the Social Science program (SPSS). The diffirences in IOP changes, $\mathrm{C} / \mathrm{D}$ ratios, $\mathrm{CCT}$ and age between groups was compared statistically with an analysis of variance (one-way ANOVA) and Tukey HSD test. Paired t test was used to compare the baseline and the follow-up IOP levels. The Pearson Chi-Square test was used to evaluate side effects, VF defects, pseudoexfoliation incidence and gender between groups. $P$ value less than 0.05 was considered statistically significant.

\section{Results}

Thirty six eyes of 18 patients were enrolled in the study. Seven patients $(38.8 \%)$ were female and $11(61.1 \%)$ male. The- re was no difference between the groups in terms of gender $(\mathrm{p}=0.154)$. The mean age was $56.5 \pm 7.8(45-68)$ in group 1 , $55.1 \pm 9.3$ (41-69) in group 2 and 62.5 \pm 10.1 (48-75) in group 3 ( $\mathrm{p}=0.138)$. POAG/OHT ratios, C/D ratios, mean CCT, pseudoexfoliation incidence were similar between the groups ( $p$ $>0.05$ ). Demographic and baseline characteristics are shown in Table 1. VF defect was a paracentral scotoma in 4 eyes in the latanoprost group (33.3\%) and 1 eye in the travoprost group $(8.3 \%)$, nasal step in 2 eyes in the travoprost group $(16.7 \%)$, paracentral scotoma in 1 eye in the bimatoprost group $(8.3 \%)$ and paracentral scotoma and peripheral concentric narrowing in 1 eye in the bimatoprost group (8.3\%). There was no significant difference between the groups in terms of VF changes $(p>0.05)$.

\begin{tabular}{|c|c|c|c|c|}
\hline & Week 2 & $p^{*}$ & Week 24 & $p^{*}$ \\
\hline Latanoprost & $10.75 \pm 4.24$ & 0.482 & $11.66 \pm 3.34$ & 0.214 \\
\hline Travoprost & $9.41 \pm 4.87$ & & $9.16 \pm 5.89$ & \\
\hline Travoprost & $9.41 \pm 4.87$ & 0.816 & $9.16 \pm 5.89$ & 0.773 \\
\hline Bimatoprost & $9.83 \pm 3.73$ & & $8.50 \pm 5.30$ & \\
\hline Latanoprost & $10.75 \pm 4.24$ & 0.580 & $11.66 \pm 3.34$ & 0.094 \\
\hline Bimatoprost & $9.83 \pm 3.73$ & & $8.50 \pm 5.30$ & \\
\hline
\end{tabular}

At baseline mean IOP levels were similar between the groups, at $26.50 \pm 3.14 \mathrm{mmHg}(23-32 \mathrm{mmHg})$ in group 1, $25.58 \pm 3.62 \mathrm{mmHg}(21-32 \mathrm{mmHg})$ in group 2 and $24.66 \pm$ $3.62 \mathrm{mmHg}(21-32 \mathrm{mmHg})$ in group $3(\mathrm{p}=0.355)$. After medical treatment, the mean IOP at the end of 2 weeks were similar between the groups; $15.75 \pm 2.66 \mathrm{mmHg}(10-19 \mathrm{mmHg})$ in group $1,16.16 \pm 2.58 \mathrm{mmHg}(10-20 \mathrm{mmHg})$ in group 2 and $14.83 \pm 2.85 \mathrm{mmHg}(12-22 \mathrm{mmHg})$ in group $3(\mathrm{p}>0.05)$. Mean IOP levels at the end of 4th, 12th and 24th weeks were also similar between the groups ( $\mathrm{p}>0.05)$. The baseline IOPs and its change during 24 weeks are shown in Table 2. Significant mean IOP reductions were obtained in all three groups by week $2(\mathrm{p}<0.001)$. IOP reductions at the 2 nd week were $10.75 \pm 4.24 \mathrm{mmHg}$ with latanoprost, $9.41 \pm 4.87 \mathrm{mmHg}$ with travoprost and $9.83 \pm 3.73 \mathrm{mmHg}$ with bimatoprost. Reductions of mean IOP at the end of 24th week compared to baseline were $11.66 \pm 3.34 \mathrm{mmHg}, 9.16 \pm 5.89 \mathrm{mmHg}$ and $8.50 \pm 5.30$ $\mathrm{mmHg}$, respectively. The biggest reduction of mean IOP was determined in the latanoprost group though not significant ( $p$ $>0.05$ ) (Table 3). The most common side effect observed in this study was conjunctival hyperemia. There was no hyperemia in group 1 , but appeared in 2 eyes $(16.7 \%)$ in group 2 and $6(50 \%)$ eyes in group 3. In addition, complaints such as

Table 2. Time-dependent changes in intra ocular pressure levels

\begin{tabular}{lccccc} 
& Baseline & Week 2 & Week 4 & Week 12 & Week 24 \\
\hline Latanoprost & $26.50 \pm 3.14$ & $15.75 \pm 2.66$ & $16.33 \pm 2.10$ & $16.08 \pm 2.27$ & $14.83 \pm 2.24$ \\
Travoprost & $25.58 \pm 3.62$ & $16.16 \pm 2.58$ & $16.41 \pm 3.17$ & $15.25 \pm 2.59$ & $16.41 \pm 4.16$ \\
Bimatoprost & $24.66 \pm 3.62$ & $14.83 \pm 2.85$ & $15.25 \pm 2.73$ & $15.33 \pm 1.92$ & $16.16 \pm 3.53$ \\
$\mathbf{p}^{* *}$ & 0.355 & 0.470 & 0.565 & 0.620 & $<0.001$ \\
\hline
\end{tabular}

$\mathrm{p}^{*}$ : Paired t Test, comparison of baseline IOP levels and week 2, 4, 12, 24 IOP levels

$\mathrm{p}^{* *}$ : One-way ANOVA, comparison of IOP levels between groups 
stinging/burning were observed in 2 eyes (16.7\%) in the latanoprost group and eyelash elongation in 2 eyes in the travoprost group. Side-effects were less frequent in the latanoprost and more common in the bimatoprost group, and the differences between the groups were statistically significant $(p<0.05)$ (Table 4).

\begin{tabular}{lccc|}
\hline Table 4. Ocular side-effects & & \\
\hline & $\begin{array}{c}\text { Latanoprost } \\
\text { group } \\
\mathrm{n}-(\%)\end{array}$ & $\begin{array}{c}\text { Travoprost } \\
\text { group } \\
\mathrm{n}-(\%)\end{array}$ & $\begin{array}{c}\text { Bimatoprost } \\
\text { group } \\
\mathrm{n}-(\%)\end{array}$ \\
\hline Hyperemia & - & $2-(16.7)$ & $6-(50)$ \\
Burning-stinging & $2-(16.7)$ & - & - \\
Eyelash growth & - & $2-(16.7)$ & - \\
\hline
\end{tabular}

\section{Discussion}

We determined significant IOP reductions with latanoprost, travoprost and bimatoprost monotherapies in patients with POAG and OHT after follow-up for 24 weeks. There was no significant difference between the three groups in terms of effectiveness on reducing the IOP. These findings are similar to those reported in the present literature. Parrish et al. (2003) reported mean IOP reduction of $8.6 \pm 0.3 \mathrm{mmHg}$ with latanoprost therapy, $8.0 \pm 0.3 \mathrm{mmHg}$ with travoprost therapy and $8.7 \pm 0.3 \mathrm{mmHg}$ with bimatoprost therapy for 12 weeks follow-up. Ozdemir et al. (2004) achieved IOP reductions of $10.7 \mathrm{mmHg}$ with latanoprost, $10.7 \mathrm{mmHg}$ with travoprost and $7.3 \mathrm{mmHg}$ with bimatoprost within 8 weeks of therapy. In his study in which patients were followed for 9 months. Şen et al. (2006) observed reductions in IOP of $7.48 \pm 4.59 \mathrm{mmHg}$ with latanoprost, $8.23 \pm 5.56 \mathrm{mmHg}$ with travoprost and $8.30 \pm 4.39$ $\mathrm{mmHg}$ with bimatoprost. DuBiner et al. (2001) determined decreases in the IOPs of $5.5 \mathrm{mmHg}$ with latanoprost and 7.0 $\mathrm{mmHg}$ with bimatoprost on the 30 th day. In a recent metaanalysis including nine studies, travoprost and bimatoprost were declared to be more effective to reduce IOP than latanoprost (Denis et al., 2007).

Stinging/burning, itching, conjunctival hyperemia, hypertrichosis, eyelid erythema, pigmentation in the iris and periocular skin, cystoid macular edema in pseudophakic and aphakic patients, recurrence of uveitis and herpes simplex keratitis, coroidal detachment and hypotonia have been reported during treatment with prostaglandin analogs (Hylton and Robin, 2003; Turaçl1, 2003). The topical side-effects in our study were less frequent in the patients receiving latanoprost, while observed more commonly in the bimatoprost group. The most frequent side-effect was conjunctival hyperemia, in concordance with the present literature. While conjunctival hyperemia was observed in none of the patients in the latanoprost group, it was detected among $16.7 \%$ of travoprost and $50 \%$ of bimatoprost groups. Parrish et al. (2003) reported the incidence of hyperemia to be $47.1 \%$ with latanoprost, $58.0 \%$ with travoprost and $68.6 \%$ with bimatoprost. Also, several studies reported less hyperemia with latanoprost compared to travoprost or bimatoprost (Stewart et al., 2003; Ozdemir et al., 2004; Sarıcaoğlu et al., 2005; Sen et al., 2006). However, Whitson et al. (2010) observed no significant differences between bimatoprost, latanoprost, and travoprost regarding objective clinical measures of ocular tolerability, including physician-graded hyperemia, corneal staining and tear breakup time after 3 months of treatment. Hyperemia has been supposed to be a result of inflammation stimulated by activation of PGF $2 \alpha$ receptors, or of toxicity and inflammation associated with the benzalkonium chloride present in the drug as a protective agent (Guenoun et al., 2005).

In addition to hyperemia, itching, stinging and sensitivity in the eye may also be encountered. In our study, the rate of itching/stinging was $16.7 \%$ with latanoprost while none was observed with the other agents. Noecker et al. (2003) reported stinging/itching in $5.9 \%$ of his patients with latanoprost and $5.2 \%$ with bimatoprost. Another prostaglandin analogassociated side-effect is the elongation and increasing numbers of eyelashes. Eyelash growth was determined in $16.7 \%$ of the patients receiving travoprost in our study, and none with the other agents. In the study of Parrish et al. (2003) no eyelash growth was reported with latanoprost and only $0.7 \%$ with travoprost and $2.9 \%$ with bimatoprost, while in the study of Noecker et al. (2003) none had eyelash growth with latanoprost, and $19.5 \%$ of the patients receiving bimatoprost had eyelash growth. Iris and periocular skin pigmentation have been reported to be $30 \%$ in the literature (Stjernschantz et al., 2002; Perry et al., 2003). However, we detected iris or periocular skin color changes in none of our patients.

Systemic side-effects such as headache, upper respiratory tract infection, flue-like syndrome and musculo-skeletal pain may be seen during treatment with prostaglandin analogs (Hylton and Robin, 2003). None of our patients reported systemic side-effects.

The PGAs, latanoprost, and travoprost bimatoprost, supply effective reductions in the IOP in the patients with POAG and OHT. All three drugs seem to be equivalently potent. PGAs should be used as the first line drug in the monotherapy of POAG and OHT. Among these drugs, latanoprost has low side-effect profile.

\section{REFERENCES}

AGIS Investigators, 2000.The advanced glaucoma intervention study (AGIS): 7. The relationship between control of intraocular pressure and visual field deterioration. Am. J. Ophthalmol. 130, 490-491.

Alexander, C.L., Miller, S.J., Abel, S.R., 2002. Prostaglandin analog treatment of glaucoma and ocular hypertension. Ann. Pharmacother. 36, 504-511.

Denis, P., Lafuma, A., Khoshnood, B., Mimaud, V., Berdeaux, G., 2007. A meta-analysis of topical prostoglandin analogues intra-ocular pressure lowering in glaucoma therapy. Curr. Med. Res. Opin. 23, 601-608.

DuBiner, H., Cooke, D., Dirks, M., Stewart, W.C., VanDenburgh, A.M., Felix, C., 2001. Efficacy and safety of bimatoprost in patients with elevated intraocular pressure: A 30-day comparison with latanoprost. Surv. Ophthalmol. 45, 353-360.

Guenoun, J.M., Baudouin, C., Rat, P., Pauly, A., Warnet, J.M., Brignole-Baudouin, F., 2005. in vitro study of potential and toxicity profile of latanoprost, travoprost, and bimatoprost in conjunctiva-derived epithelial cells. Invest. Ophthalmol. Vis. Sci. 46, 2444-2450.

Hylton, C., Robin, A.L., 2003. Update on prostaglandin analogs. Curr. Opin. Ophthalmol. 14, 65-69.

Netland, P.A., Landry, T., Sullivan, E.K., Andrew, R., Silver, L., Weiner, A.K., Mallick, S., Dickerson, J., Bergamini, M.V.W., Robertson, S.M., Davis, A.A., 2001. Travoprost compared with latanoprost and timolol in patients with open-angle glaucoma and ocular hypertension. Am. 
J. Ophthalmol. 132, 472-484.

Noecker, R.S., Dirks, M.S., Choplin, N.T., Bernstein, P., Batoosingh, A.L., Whitcup, S.M., 2003. The Bimatoprost/Latanoprost Study Group. A six-month randomized clinical trial comparing the intraocular pressure-lowering efficacy of bimatoprost and latanoprost in patients with ocular hypertension or glaucoma. Am. J. Opthalmol. 135, 55-63.

Ozdemir, N., Ozcan, A.A., Bilgiç, E., 2004. Bimatoprost, latanoprost ve travoprostun primer açık açılı glokom olgularında erken dönem yan etkileri ve göz içi basıncı üzerine etkinliği. T. Oft. Gaz. 33, 376-379.

Parrish, R.K., Palmberg, P., Sheu, W.P., 2003. A comparison of latanoprost, bimatoprost, and travoprost in patients with elevated intraocular pressure: A 12 week randomized, masked-evaluator multicenter study. Am. J. Ophthalmol. 135, 688-703.

Perry, C.M., McGavin, J.K., Culy, C.R., Ibbotson, T., 2003. Latanoprost an update of its use in glaucoma and ocular hypertension. Drugs Aging. 20, 597-630.

Sarıcaoğlu, M.S., Karakurt, A., Sengün, A., Hasıripi, H., Karabulut, E., 2005. Primer açık açılı glokom olgularında latanoprost, travoprost ve bimatoprostun yan etki profillerinin karşıllaştırılması. M.N. Oftalmoloji. 12, 113-117.

Sen, E.M., Tuna, T., Ural, F., Köklü, G., Fırat, E., 2006. Primer açık açılı glokom hastalarının tedavisinde latanoprost, travoprost ve bimatoprostun karşılaştırılması. T. Klin. J. Ophthalmol. 15, 12-17.

Sherwood, M., Brandt, J., 2001. For the Bimatoprost Study Groups 1 and 2. Six-month comparison of bimatoprost once-daily and twice-daily with timolol twice-daily in patients with elevated intraocular pressure. Surv. Ophthalmol. 45, 361-368.

Smith, M.F., Doyle, J.W., 2004. Clinical examination of glaucoma. In Ophthalmology. Yanoff M., Duker J.S., eds. 11830 Westline Industrial Drive, St. Louis. 1431-1440

Stewart, W.C., Kolker, A.E., Stewart, J.A., Leech, J., Jackson, A.L., 2003. Conjunctival hyperemia in healty subjects after short-term dosing with of latanoprost, bimatoprost, and travoprost. Am. J. Ophthalmol. 135, 314-320.

Stjernschantz, J.W., Albert, D.M., Hu, D.N., Drago, F., Wistrand, P.J., 2002. Mechanism and clinical significance of prostoglandin induced iris pigmentation. Surv. Ophthalmol. 47, 162-175.

Turaçlı, M.E., 2003. Tıbbi tedavi. In Glokom. Turaçlı M.E., Onol M., Yalvaç I.S., eds. SFN Televizyon Tanıtım Tasarım Yayıncılık, Ankara, pp. 163-195.

Watson P., Stjernschantz, J., 1996. For the Latanoprost Study Group. A six-month, randomized, double-masked study comparing latanoprost with timolol in open-angle glaucoma and ocular hypertension. Ophthalmology. 103, 126-137.

Whitson, J.T., Trattler, W.B., Matossian, C., Williams, J., Hollander, D.A., 2010. Ocular surface tolerability of prostaglandin analogs in patients with glaucoma or ocular hypertension. J. Ocul. Pharmacol. Ther. 26, 287-292. 